\title{
Publisher Correction: Long-term culture of human pancreatic slices as a model to study real-time islet regeneration
}

\author{
Mirza Muhammad Fahd Qadir (D), Silvia Álvarez-Cubela, Jonathan Weitz, Julia K. Panzer, Dagmar Klein, \\ Yaisa Moreno-Hernández, Sirlene Cechin, Alejandro Tamayo, Joana Almaça, Helmut Hiller, Maria Beery (D), \\ Irina Kusmartseva, Mark Atkinson, Stephan Speier (D, Camillo Ricordi, Alberto Pugliese, Alejandro Caicedo, \\ Christopher A. Fraker, Ricardo Luis Pastori \& Juan Domínguez-Bendala (i)
}

Correction to: Nature Communications https://doi.org/10.1038/s41467-020-17040-8, published online 29 June 2020.

The original version of this Article was updated shortly after publication, to replace an incorrect version of the Peer Review File. The error has now been fixed and the Peer Review File PDF is available to download from the HTML version of the Article.

Published online: 22 July 2020

\begin{abstract}
(c) (i) Open Access This article is licensed under a Creative Commons Attribution 4.0 International License, which permits use, sharing, adaptation, distribution and reproduction in any medium or format, as long as you give appropriate credit to the original author(s) and the source, provide a link to the Creative Commons license, and indicate if changes were made. The images or other third party material in this article are included in the article's Creative Commons license, unless indicated otherwise in a credit line to the material. If material is not included in the article's Creative Commons license and your intended use is not permitted by statutory regulation or exceeds the permitted use, you will need to obtain permission directly from the copyright holder. To view a copy of this license, visit http://creativecommons.org/licenses/by/4.0/.
\end{abstract}

(C) The Author(s) 2020 